\title{
Perancangan Aplikasi Sistem Informasi Geotrack Administrasi Surat Berbasis Website
}

\author{
Stepanus Pande Abednigo ${ }^{1}$, Anita Muliawati ${ }^{2}$, Bambang Tri Wahyono $^{3}$ \\ ${ }^{1}$ Program Studi Sistem Informasi, Universitas Pembangunan Nasional Veteran Jakarta, Jl. Rs. \\ Fatmawati, Pondok Labu, Jakarta Selatan, DKI Jakarta, Indonesia, 12450 \\ e-mail: ${ }^{1}$ stepanuspandes@gmail.com, ${ }^{2}$ anitamuliawati@upnvj.ac.id, \\ 3bambangtriwahyono@upnvj.ac.id
}

Submitted Date: September $08^{\text {th }}, 2020$

Revised Date: October $29^{\text {th }}, 2020$

\author{
Reviewed Date: September $28^{\text {th }}, 2020$ \\ Accepted Date: January $04^{\text {th }}, 2021$
}

\begin{abstract}
This research was conducted to find out how the management process that covers sending sample letters and follow-up letter dispositions at PT Aneka Tambang Tbk's work unit, Geomin Unit to improve the effectiveness of inter-work unit coordination. This research is also motivated by the problem of an ineffective system that monitors the progress of sample analysis. Because in its development, coordination between the laboratory and the team is carried out not computerized. Coordination is not computerized by contacting the relevant parties via private chat, telephone or email. In designing this application using the Waterfall method. The programming languages are HTML and PHP. For Framework using Bootstrap, and for the database using MySQL. Supporting applications used are XAMPP, Sublime Text, and PhpMyAdmin. The final result of this research is a website-based monitoring and tracking application for mail management. It can be concluded that the design of this application provides many benefits in the process of managing letter data, especially in PT Aneka Tambang Tbk, Geomin Unit.
\end{abstract}

Keywords: Letter Management; Web Based Application; Letter Monitoring;

\begin{abstract}
Abstrak
Penelitian ini dilakukan untuk mengetahui bagaimana implementasi proses pengelolaan administrasi yang melingkupi pengiriman surat sampel dan tindaklanjut disposisi surat pada satuan kerja PT Aneka Tambang Tbk, Unit Geomin untuk meningkatkan efektivitas koordinasi antarsatuan kerja. Penelitian ini juga dilatarbekangi dengan permasalahan yaitu tidak efektifnya sistem yang memonitor progress analisis sampel. Karena dalam memantau progressnya, koordinasi antarpihak laboratorium dan tim lapangan dilakukan secara tidak terkomputerisasi. Koordinasi secara tidak terkomputerisasi dilakukan dengan menghubungi pihak terkait lewat personal chat, telepon atau email. Dalam perancangan aplikasi ini menggunakan metode Waterfall. Bahasa pemrogramnya adalah HTML dan PHP. Untuk Framework menggunakan Bootstrap, dan untuk basis datanya menggunakan MySQL. Aplikasi pendukung yang digunakan adalah XAMPP, Sublime Text, dan PhpMyAdmin. Hasil akhir penelitian ini adalah aplikasi monitoring dan tracking pengelolaan surat berbasis website, dapat disimpulkan bahwa dalam perancangan aplikasi ini memberikan banyak kemudahan dalam proses pengelolaan data surat khususnya di PT Aneka Tambang Tbk, Unit Geomin.
\end{abstract}

Kata kunci: Manajemen Surat; Aplikasi Berbasis Web; Pemantauan Surat;

\section{Pendahuluan}

In Unit Geomin adalah salah satu dari lima unit operasi PT ANTAM (Persero) Tbk ("ANTAM"). Unit Geomin memiliki visi penemuan sumber daya mineral yang diwujudkan dengan kegiatan eksplorasi, yang mengutamakan keselamatan kerja dan kelestarian lingkungan. Eksplorasi sumber daya mineral terdiri dari beberapa rangkaian kegiatan seperti, desktop study, pemetaan regional, pemetaan detail, dan pengeboran. Keberlanjutan tahapan eksplorasi sangat ditentukan berdasarkan sampel yang 
diambil dilapangan. Sampel merupakan material yang diambil karena dianggap merepresentasikan keadaan geologi pada daerah eksplorasi yang dapat berupa tanah, batuan dan mineral sedimen sungai. Oleh karena itu, setiap informasi yang berkaitan dengan pelaporan proses pengiriman dan analisis sampel sangat penting, dan harus diketahui oleh tim yang bersangkutan.

Dari penjelasan uraian diatas, tugas lain dari Unit Geomin adalah menginformasikan dalam bentuk Surat-menyurat kepada satuan kerja Eksplorasi, GGD, Laboratorium Geomin, dan MRD. Pada GGD (Geospatial \& Geology Database) memiliki tugas yaitu memanajemen geospasial dan basis data yang bertujuan untuk penentuan posisi, pemetaan, analisis spasial, analisis geologi, pemrograman, dan pemodelan 3D dan MRD (Mineral Resources Database) memiliki tugas yaitu mengumpulkan laporan yang menggambarkan sumber daya mineral logam dan non logam. Termasuk didalamnya adalah nama deposit, lokasi komoditas, deskripsi deposit, karakteristik geologi, produksi cadangan, sumber daya, dan referensi. Dengan tugasnya ini ada permasalahan yang dihadapi dalam hal ini adalah tidak efektifnya sistem yang memonitor progress analisis sampel Karena dalam memantau progressnya, koordinasi antarpihak laboratorium dan tim lapangan dilakukan secara tidak terkomputerisasi. Koordinasi secara tidak terkomputerisasi dilakukan dengan menghubungi pihak terkait lewat personal chat, telepon atau email. Masalah timbul ketika nomor sampel tidak sesuai dengan yang tertulis pada surat sampel, atau analisis sampel tidak keluar pada jangka waktu yang ditargetkan. Sehingga tim lapangan harus melakukan konfirmasi secara personal chat atau email kepada pihak laboratorium. Metode yang digunakan dalam perancangan aplikasi geotrack administrasi adalah metode waterfall.

\section{Landasan Teori}

\subsection{Sistem Informasi}

Menurut Fridayanthie dan Charter (2016:65) mendefinisikan sistem informasi adalah kegiatan dari prosedur yang di organisasikan yang digunakan untuk menyediakan informasi pengambilan keputusan dan pengendalian didalam organisasi.

\subsection{Surat}

Surat adalah suatu alat yang digunakan untuk berkomunikasi secara tertulis yang dilakukan oleh suatu pihak kepihak lain untuk menginformasikan suatu hal yang bersifat resmi maupun tidak resmi agar tersampaikan tanpa harus berhadapan secara personal.

\subsection{Use Case Diagram}

Menurut Tohari dalam Tabrani dan Aghniya (2019:46) menyimpulkan bahwa, "use case adalah rangkaian atau uraian sekelompok yang saling terkait dan membentuk sistem secara teratur yang dilakukan atau diawasi oleh sebuah aktor".

\subsection{Entity Relationship Diagram}

Menurut Sukamto dan Shalahuddin (2018:30), menyimpulkan bahwa "entity relationship diagram (ERD) adalah sebuah diagram yang digunakan untuk merancang hubungan antar tabel-tabel dalam basis data".

\subsection{Activity Diagram}

Menurut Tohari dalam Tabrani dan Aghniya (2019:45), mendefinisikan bahwa, "activity diagram memodelkan workflow proses bisnis dan urutan aktifitas dalam sebuah proses. Diagram ini sangat mirip dengan flowchart karena memodelkan workflow dari suatu aktifitas lainnya atau dari aktifitas ke status.

\subsection{Sequence Diagram}

Menurut Tohari dalam Tabrani dan Aghniya (2019:46), menyimpulkan bahwa, "sequence diagram menggambarkan interaksi antara sejumlah objek dalam urutan waktu.

\section{Metode Penelitian}

\subsection{Metode Pengumpulan Data}

Metode pengumpulan data yang digunakan dalam penelitian ini yaitu dengan menggunakan metode observasi, metode wawancara, dan metode studi pustaka.

\subsection{Metode Pengembangan Perangkat Lunak}

Pembuatan Sistem Informasi penelitian ini metode yang digunakan dalam pengembangan perangkat lunak menggunakan model waterfall dimana model ini menurut Imroatus, dkk dalam Apriliah, dkk (2018:30), merupakan suatu model klasik yang bersifat terstruktur dalam pembuatan perangkat lunak, yang terbagi atas lima tahap, yaitu:

1. Analisis Kebutuhan Sistem

Metode Sistem usulan pengelolaan surat dimuai ketika satuan kerja Eksplorasi mendapat sampel dan memberi nomor surat 
sampel, satuan kerja Eksplorasi, GGD, Laboratorium, dan MRD melakukan pendaftaran akun aplikasi geotrack melalui admin geotrack. Setelah mendapat akun, Eksplorasi melakukan input data surat sampel melalui aplikasi geotrack, selanjutnya mengirimkan surat kepada satuan kerja GGD. GGD mengecek kesusuaian sampel dengan nomor surat, jika sudah sesuai maka GGD meneruskan kepada satuan kerja laboratorium melalui aplikasi geotrack, selanjutnya laboratorium mengkonfirmasi surat melalui aplikasi geotrack bahwa posisi surat sudah berada di laboratorium, jika tidak ada kendala maka laboratorium meneruskan kepada satuan kerja MRD, selanjutnya MRD melakukan konfirmasi bahwa posisi surat sudah berada di MRD. Nantinya satuan kerja yang menggunakan aplikasi geotrack akan disuguhkan tampilan aplikasi yang menarik.

2. Desain

Pada proses ini dilakukan proses desain rancangan sistem dengan menggunakan diagram UML antara lain use case, activity diagram, sequence, dan rancangan database menggunakan entity relationship diagram.

3. Pengkodean

Setelah melalui tahap analisa kebutuhan sistem dan desain tahap selanjutnya dilakukan tahap pengkodean dimana desain yang sudah dibuat pada tahap desain perlu ditranslasikan ke dalam bentuk sebuah aplikasi sistem informasi. Aplikasi sistem informasi yang dibangun dalam penelitian ini menggunakan Bahasa pemrograman PHP.

4. Pengujian

Pada proses ini dilakukan tahap pengujian dilakukan dengan cara mendeskripsikan hasil menggunakan blackbox testing untuk pengujian dimaksudkan untuk mengetahui apakah fungsi-fungsi pada program berjalan sesuai dengan spesifikasi yang dibutuhkan oleh user.

\section{Hasil Dan Pembahasan}

\subsection{Identifikasi Masalah}

Metode dalam melakukan idetifikasi masalah menggunakan PIECES, Metode PIECES memiliki enam variabel evaluasi yaitu Perfomance, Information, Economic, Control, Efficiency, dan Service. Berikut ini penjelasan masing-masing variabel menggunakan Tabel matriks PIECES.
Tabel 1. Identifikasi Masalah

\begin{tabular}{|c|c|c|}
\hline No & $\begin{array}{c}\text { Jenis } \\
\text { Variabel }\end{array}$ & $\begin{array}{c}\text { Analisis } \\
\text { Sistem }\end{array}$ \\
\hline 1. & $\begin{array}{l}\text { Perfomance } \\
\text { (kinerja) }\end{array}$ & $\begin{array}{l}\text { Pada sistem berjalan, sistem } \\
\text { administrasi surat di unit geomin } \\
\text { PT Aneka Tambang Tbk. } \\
\text { menerapkan sistem informasi } \\
\text { yang belum terkomputerisasi dan } \\
\text { menilai kinerja sistem yang } \\
\text { belum mampu memberikan } \\
\text { layanan informasi secara cepat } \\
\text { dan dapat dilihat kapan saja dan } \\
\text { di mana saja. }\end{array}$ \\
\hline 2. & $\begin{array}{l}\text { Information } \\
\text { (informasi) }\end{array}$ & $\begin{array}{l}\text { Pada sistem berjalan, untuk } \\
\text { memperoleh informasi mengenai } \\
\text { disposisi surat sampel masih } \\
\text { harus menghubungi pihak terkait } \\
\text { menggunakan telepon atau } \\
\text { email, sehingga tim lapangan } \\
\text { harus melakukan konfirmasi } \\
\text { secara personal chat atau email } \\
\text { kepada pihak laboratorium. }\end{array}$ \\
\hline 3. & $\begin{array}{l}\text { Economic } \\
\text { (ekonomi) }\end{array}$ & $\begin{array}{l}\text { Pada sistem berjalan, pengiriman } \\
\text { surat sampel dari tim lapangan } \\
\text { menuju laboratorium dilakukan } \\
\text { menggunakan jasa pengiriman } \\
\text { kurir, Dalam jangka waktu yang } \\
\text { lama penggunaan jasa kurir } \\
\text { membutuhkan pengeluaran yang } \\
\text { cukup besar. }\end{array}$ \\
\hline 4. & $\begin{array}{l}\text { Control } \\
\text { (pengendalian) }\end{array}$ & $\begin{array}{l}\text { Pada sistem berjalan, sistem } \\
\text { administrasi surat di unit geomin } \\
\text { PT Aneka Tambang Tbk, belum } \\
\text { mampu memonitor dan } \\
\text { pelacakan data surat sampel } \\
\text { secara efektif. }\end{array}$ \\
\hline 5. & $\begin{array}{l}\text { Efficiency } \\
\text { (Efisensi) }\end{array}$ & $\begin{array}{l}\text { Pada sistem berjalan, kegiatan } \\
\text { koordinasi disposisi surat } \\
\text { antarsatuan kerja masih } \\
\text { mengalami kendala, yaitu tidak } \\
\text { ada sistem yang dapat } \\
\text { memonitor progres analisis } \\
\text { sampel, dari lapangan hingga } \\
\text { laboratorium. }\end{array}$ \\
\hline 6. & $\begin{array}{l}\text { Service } \\
\text { (pelayanan) }\end{array}$ & $\begin{array}{l}\text { Sistem administrasi surat yang } \\
\text { dirasakan oleh pihak unit geomin } \\
\text { masih kurang efektif, membuat } \\
\text { kinerja antarsatuan kerja menjadi } \\
\text { kurang optimal. Koordinasi } \\
\text { antar-satuan kerja masih belum } \\
\text { tepat sesuai dengan waktu yang } \\
\text { dibutuhkan Sehingga dapat } \\
\text { dikatakan sistem yang lama } \\
\text { belum dapat memberikan } \\
\text { layanan yang baik. }\end{array}$ \\
\hline
\end{tabular}




\subsection{Solusi Pemecahan Masalah}

Pemecahan masalah yang penulis gunakan untuk menyelesaikan masalah yaitu mengganti sistem administrasi surat yang berjalan di unit geomin PT Aneka Tambang Tbk, dengan sistem yang terkomputerisasi berbasis menggunakan framework front-end Bootstrap. Sehingga diharapkan tidak akan terjadi lagi pemrosesan pemantauan dan pelacakan surat sampel yang memakan banyak waktu dan meminimalisir suatu kesalahan disposisi surat. Secara umum sistem yang akan dikembangkan yaitu aplikasi geotrack administrasi Surat berbasis website. Serta proses koordinasi antarsatuan dapat berjalan dengan efektif. Sistem atau aplikasi ini juga dapat membantu pihak unit geomin dalam menjalankan kegiatan usahanya dengan lancar dan aman.

\subsection{Analisis Kebutuhan Sistem}

Sistem usulan pengelolaan surat dimuai ketika satuan kerja Eksplorasi mendapat sampel dan memberi nomor surat sampel, satuan kerja Eksplorasi, GGD, Laboratorium, dan MRD melakukan pendaftaran akun aplikasi geotrack melalui admin geotrack. Setelah mendapat akun, Eksplorasi melakukan input data surat sampel melalui aplikasi geotrack, selanjutnya mengirimkan surat kepada satuan kerja GGD. GGD mengecek kesusuaian sampel dengan nomor surat, jika sudah sesuai maka GGD meneruskan kepada satuan kerja laboratorium melalui aplikasi geotrack, selanjutnya laboratorium mengkonfirmasi surat melalui aplikasi geotrack bahwa posisi surat sudah berada di laboratorium, jika tidak ada kendala maka laboratorium meneruskan kepada satuan kerja MRD, selanjutnya MRD melakukan konfirmasi bahwa posisi surat sudah berada di MRD. Nantinya satuan kerja yang menggunakan aplikasi geotrack akan disuguhkan tampilan aplikasi yang menarik.

\subsection{Perncangan Sistem dan Desain Sistem}

1. Use Case Diagram Eksplorasi

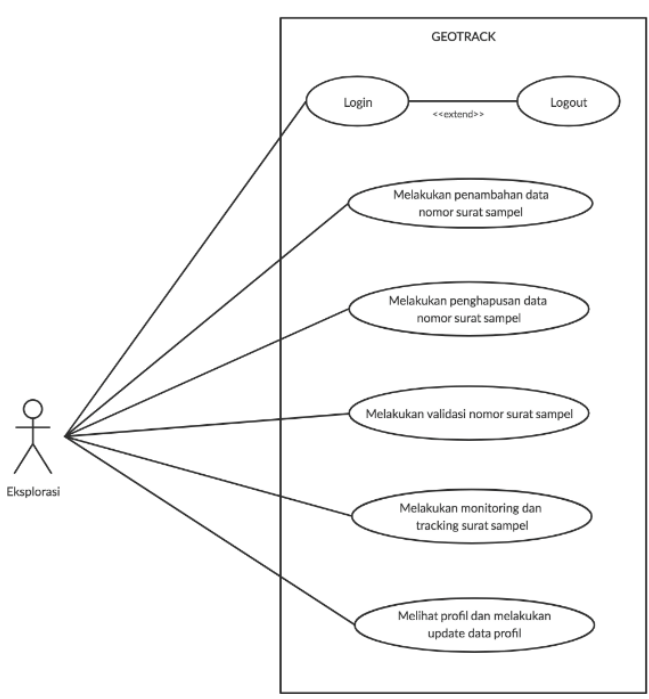

Gambar 1. Use Case Diagram Eksplorasi

Gambar di atas menjelaskan alur sistem yang dilakukan oleh aktor Eksplorasi, mulai dari login, melakukan penambahan data nomor surat sampel, penghapusan data nomor surat sampel, validasi nomor surat sampel, monitoring dan tracking surat sampel, melihat profil dan melakukan update data profil.

\section{Use Case Diagram GGD}

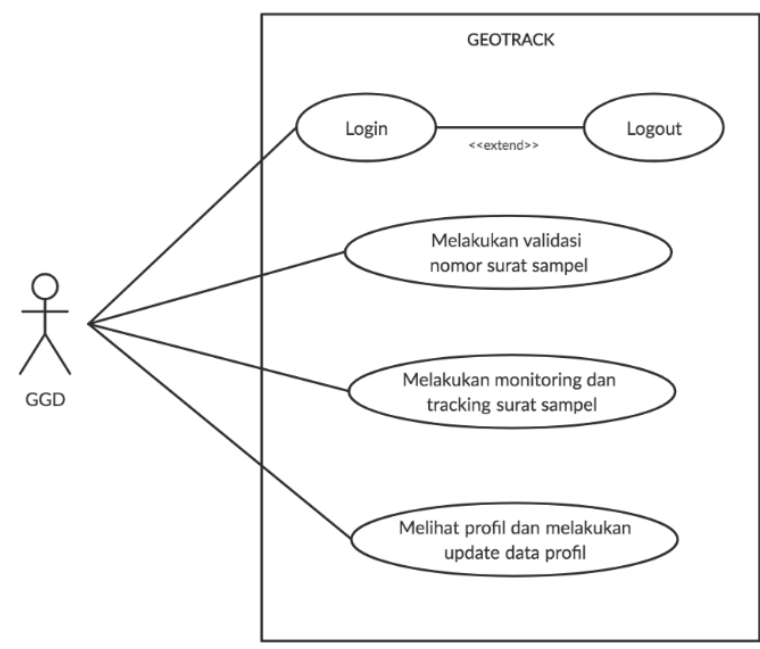

Gambar 2. Use Case Diagram GGD

Gambar di atas menjelaskan alur sistem yang dilakukan oleh aktor GGD (Geospatial \& Geology Database), mulai dari login, melakukan validasi nomor surat sampel, melakukan monitoring dan tracking surat sampel, melihat profil dan melakukan update data profil. 


\section{Use Case Diagram Laboratorium}

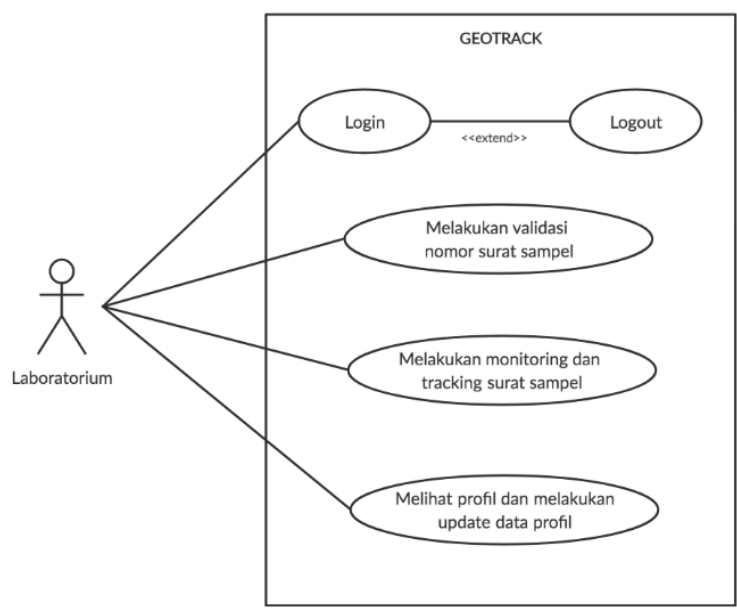

Gambar 3. Use Case Diagram Laboratorium

Gambar di atas menjelaskan alur sistem yang dilakukan oleh aktor laboratorium, mulai dari login, melakukan validasi nomor surat sampel, melakukan monitoring dan tracking surat sampel, melihat profil dan melakukan update data profil.

\section{Use Case Diagram MRD}

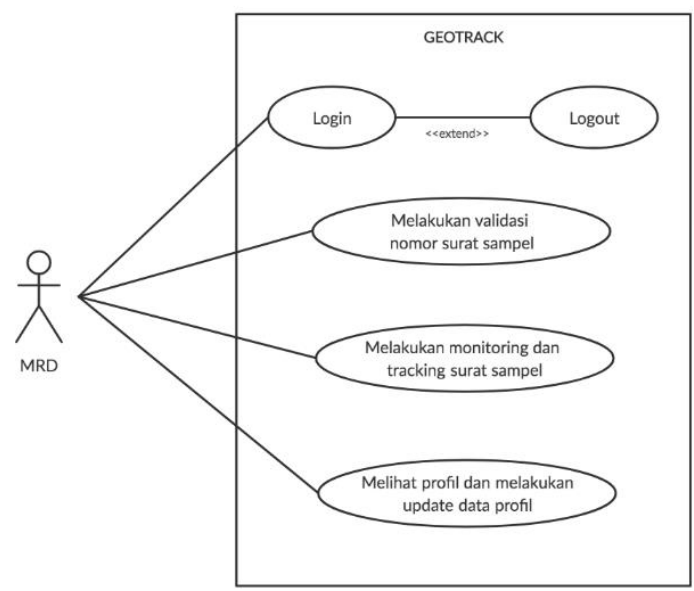

Gambar 4. Use Case Diagram MRD

Gambar di atas menjelaskan alur sistem yang dilakukan oleh aktor MRD (Mineral Resource Database), mulai dari login, melakukan validasi nomor surat sampel, melakukan monitoring dan tracking surat sampel, melihat profil dan melakukan update data profil.

\section{Activity Diagram Eksplorasi}

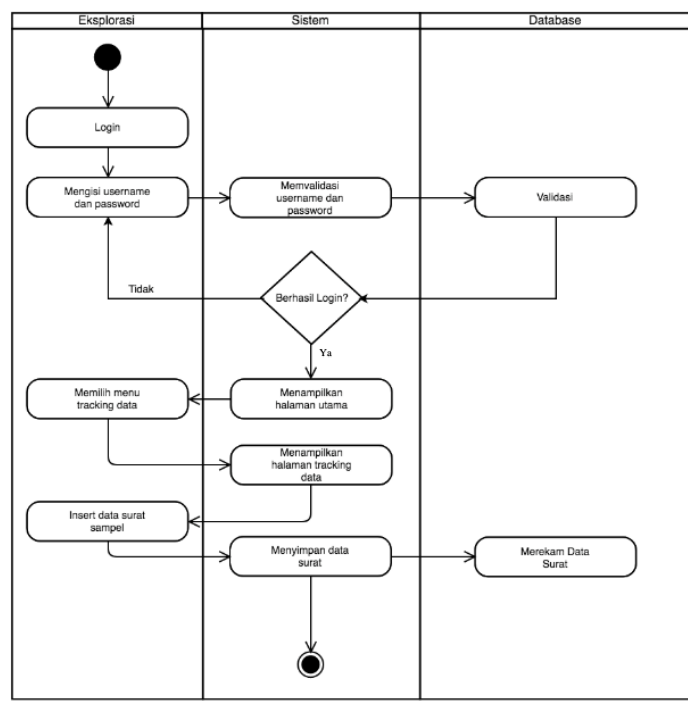

Gambar 5. Activity Diagram Eksplorasi

Activity diagram eksplorasi adalah aktivitas yang dilakukan oleh aktor eksplorasi dengan mengisi username dan password kemudian akan di validasi oleh sistem, setelah sistem memverifikasi dan berhasil login maka akan menampilkan halaman utama. Selanjutnya eksplorasi dapat menambah data surat, mengubah data nomor surat, validasi surat, dan menghapus data surat.

\section{Activity Diagram GGD}

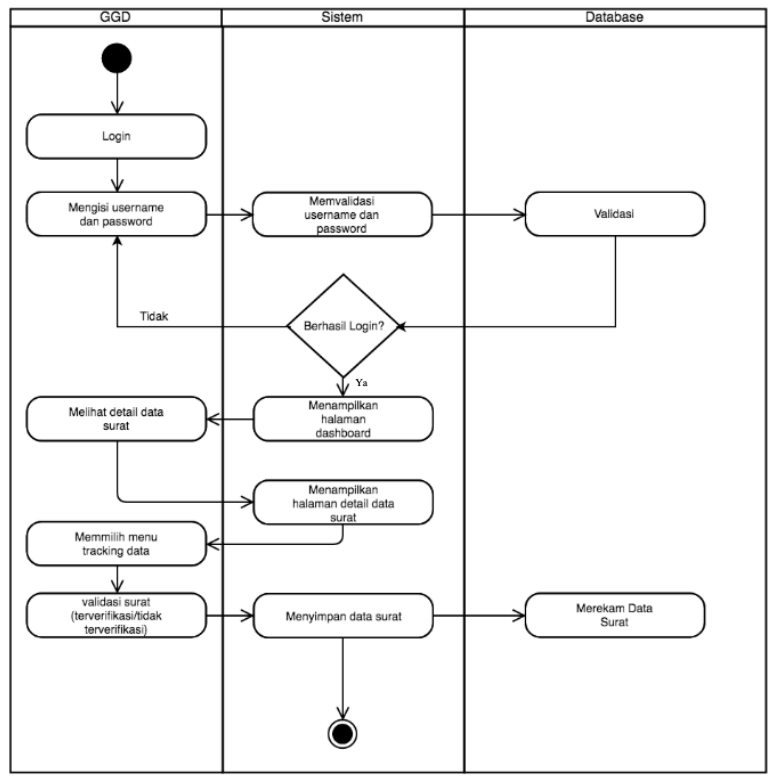

Gambar 6. Activity GGD

Activity diagram GGD adalah aktivitas yang dilakukan oleh (Geospasial \& Geology Database) yaitu memasukkan username dan password, kemudian akan di validasi oleh sistem, setelah 
sistem berhasil memverifikasi dan berhasil login maka akan menampilkan halaman dashboard. Selanjutnya GGD dapat melihat detail data surat dan melaukan validasi surat di halaman tracking data.

\section{Activity Diagram Laboratorium}

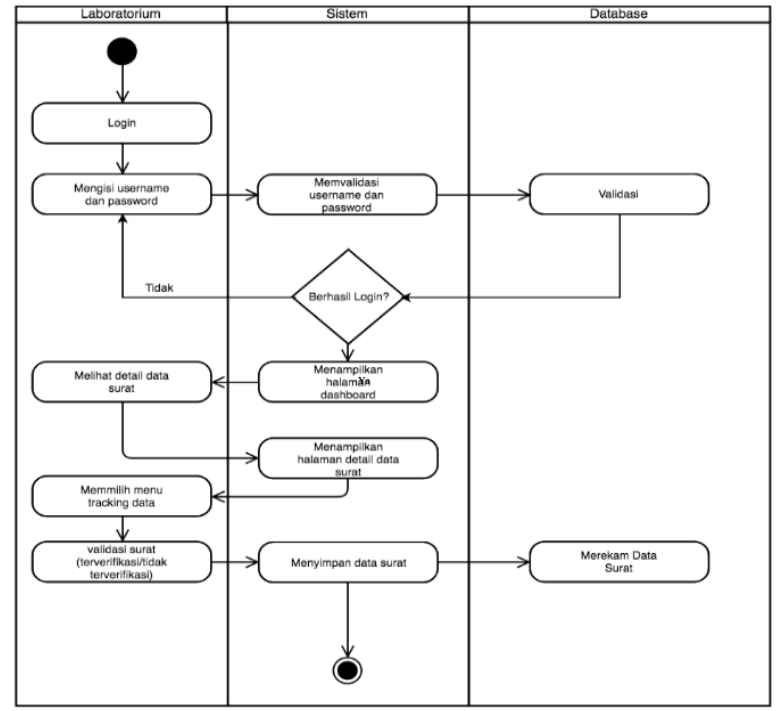

Gambar 7. Activity Diagram Laboratorium

Activity diagram laboratorium adalah aktivitas yang dilakukan oleh laboratorium dengan mengisi username dan password, kemudian di validasi oleh sistem, setelah sistem berhasil memverifikasi dan berhasil login maka akan menampilkan halaman dashboard. Selanjutnya laboratorium dapat melihat detail data surat dan validasi surat sampel di halaman tracking data.

\section{Activity Diagram MRD}

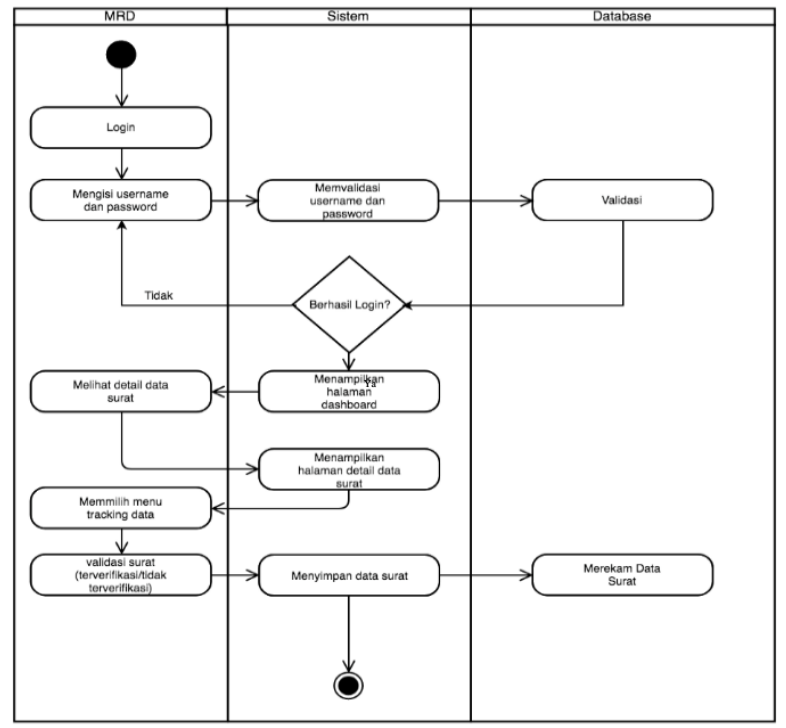

Gambar 8. Activity Diagram MRD
Activity diagram MRD adalah aktivitas yang dilakukan oleh aktor MRD (Mineral Resources Database) dengan mengisi username dan password, kemudian di validasi oleh sistem, setelah sistem berhasil memverifikasi dan berhasil login maka akan menampilkan halaman dashboard. Selanjutnya MRD dapat melihat detail data surat dan validasi surat sampel di halaman tracking data.

\section{Class Diagram}

Berikut ini digambarkan class diagram aplikasi sistem informasi geotrack administrasi surat.
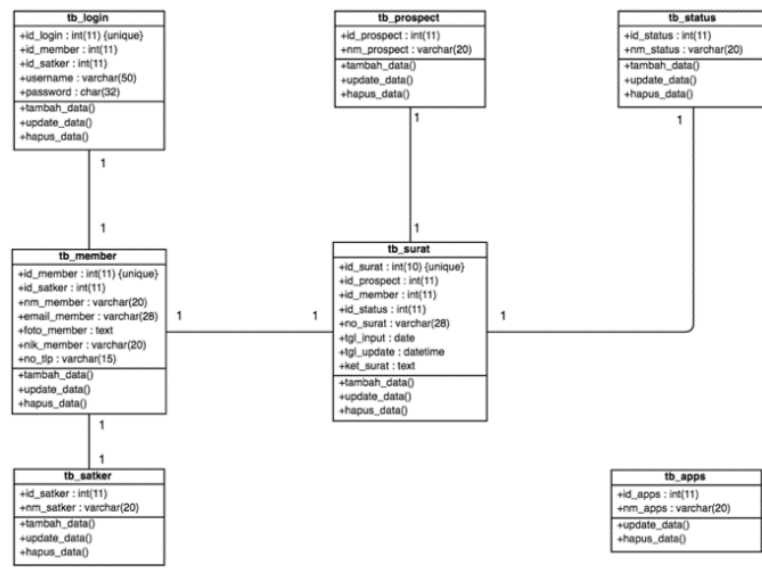

Gambar 9. Class Diagram

\subsection{Rancangan Kode}

Rancangan kode ini terdiri dari angka yang dibuat untuk mengidentifikasi sebuah objek dengan singkat, agar dapat mengklasifikasikan objek tersebut.

1. Nomor Surat Sampel SM01/01/EKSPLORASI/2020

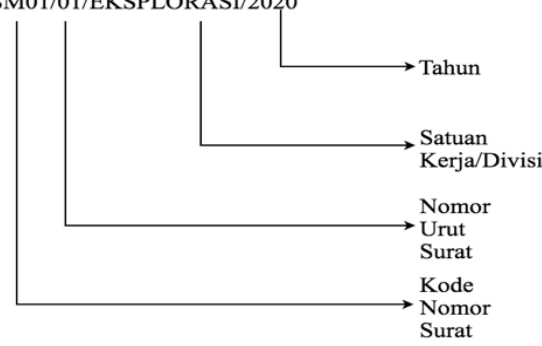


4.6 Rancangan Graphycal User Interface

1. Rancangan Interface Login

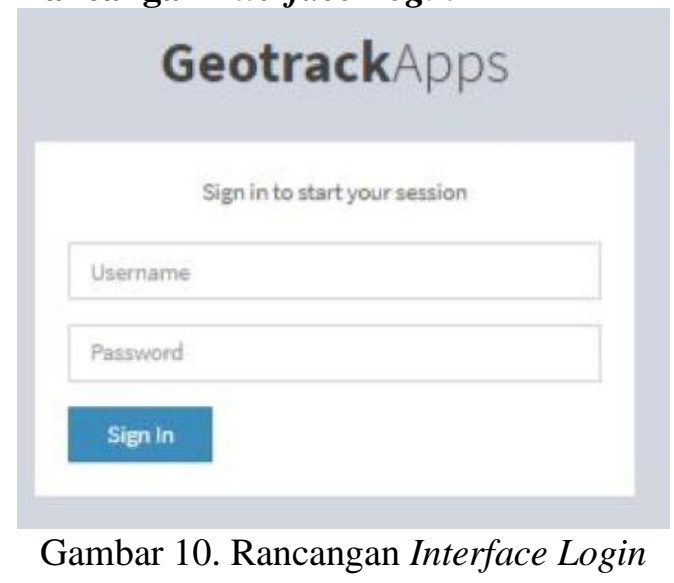

Pada halaman Login, pengguna yang sudah mendapat hak akses bisa memasukkan username dan password untuk masuk ke dalam sistem.

\section{Rancangan Interface User Profil}

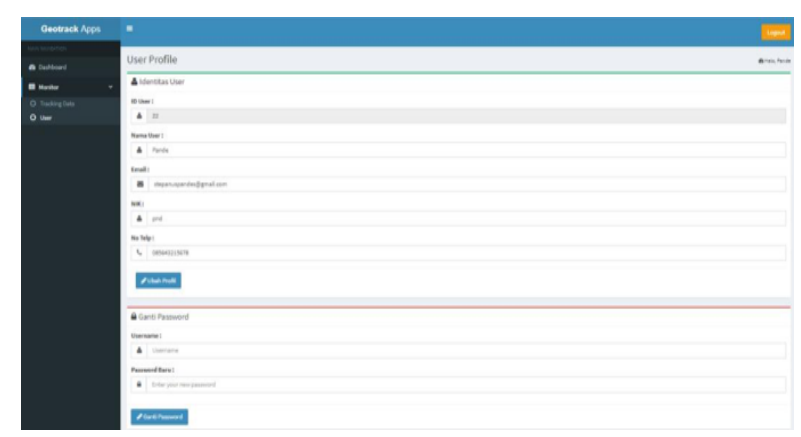

Gambar 11. Rancangan Interface User Profil

Rancangan Interface menu User Profil merupakan menu untuk mengubah data profil dan mengganti password.

\section{Rancangan Interface Dashboard}

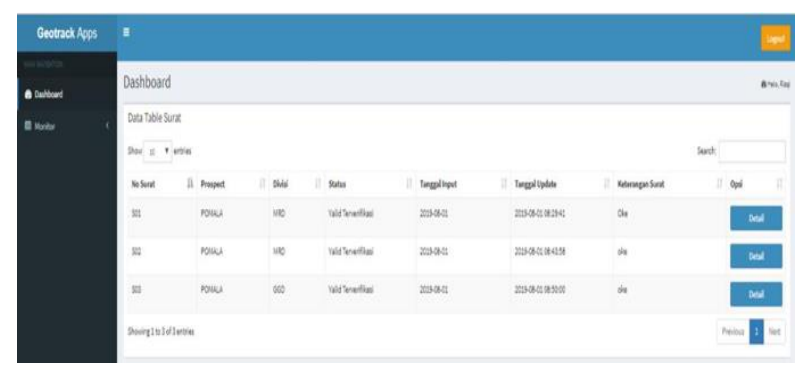

Gambar 12. Rancangan Interface Dashboard

Pada halaman Dashboard, pengguna dapat melihat seluruh aktivitas yang ada pada website mengenai data tracking yang sedang dikerjakan oleh seluruh pengguna diantaranya No Surat, Prospect, Divisi, Status, Tanggal Input, Tanggal
Update, dan Keterangan Surat. Selain itu terdapat fungsi search, berfungsi untuk membantu pengguna dalam pencarian data yang ada pada aplikasi.

\section{Rancangan Interface Detail Data Tracking}

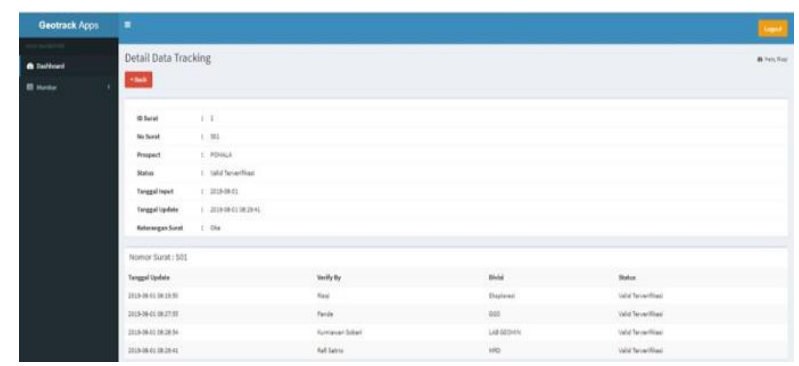

Gambar 13. Rancangan Interface Detail Data Tracking

Pada halaman Detail Data Tracking memiliki fungsi untuk mengetahui sejauh mana nomor surat tertentu telah dikerjakan. Pengguna bisa memilih icon detail data tracking pada bagian opsi untuk melihat perkembangan data apakah masih diverifikasi oleh setiap satuan kerja.

\section{Rancangan Interface Tracking Data}

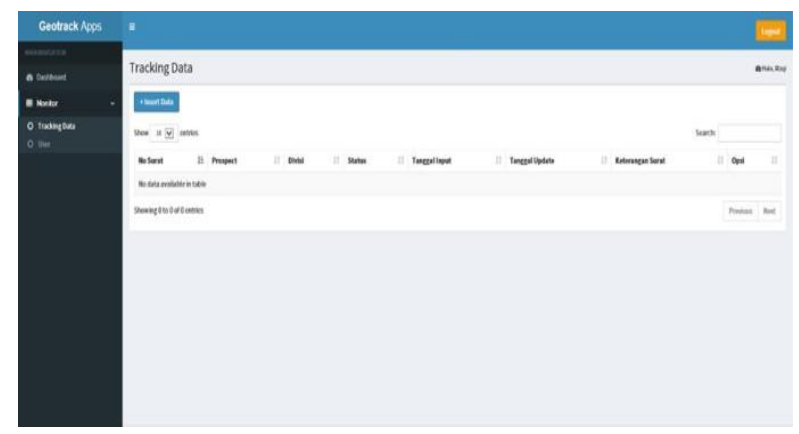

Gambar 14. Rancangan Interface Tracking Data

Pada halaman Tracking Data, masing-masing satuan kerja atau divisi memiliki hak akses berbeda. Pada halaman tracking data, penambahan data surat hanya bisa dilakukan oleh satuan kerja eksplorasi.

\subsection{Pengujian}

Pada tahap akhir dilakukan pengujian website GEOTRACK dengan memakai metode Balckbox Testing. Pengujian sistem ini dilakukan dengan tujuan untuk mendeteksi apakah seluruh modul yang dibuat berjalan sesuai dengan rencana dan tidak memiliki kesalahan-kesalahan terhadap proses ataupun bug pada website GEOTRACK. 
Tabel 2. Pengujian

\begin{tabular}{|l|l|}
\hline \multicolumn{1}{|c|}{$\begin{array}{c}\text { Nama } \\
\text { Kasus Uji }\end{array}$} & \multicolumn{1}{|c|}{ Validasi Data Surat } \\
\hline $\begin{array}{l}\text { Tujuan } \\
\text { Pengujian }\end{array}$ & $\begin{array}{l}\text { Menjamin bahwa sistem mampu } \\
\text { menyelesaikan proses validasi data } \\
\text { surat jika data yang dimasukkan } \\
\text { sesuai dan benar. }\end{array}$ \\
\hline $\begin{array}{l}\text { Prosedur } \\
\text { Uji }\end{array}$ & $\begin{array}{l}\text { 1. Mengklik opsi icon pensil pada } \\
\text { menu tracking data } \\
\text { 2. Mengklik status dan memilih } \\
\text { status valid terverifikasi. }\end{array}$ \\
\hline $\begin{array}{l}\text { Hasil yang } \\
\text { diharapkan }\end{array}$ & $\begin{array}{l}\text { Pengguna dapat melihat detail data } \\
\text { status surat, nomor surat, dan } \\
\text { keterangan surat, setelah itu } \\
\text { pengguna dapat mengubah status } \\
\text { data surat dan melakukan validasi } \\
\text { data surat berdasarkan nomor surat, } \\
\text { status dan keterangan surat. }\end{array}$ \\
\hline $\begin{array}{l}\text { Pengguna berhasil mengubah status } \\
\text { surat dari tidak terverifikasi menjadi } \\
\text { valid terverifikasi. }\end{array}$ \\
\hline Pengujian
\end{tabular}

\subsection{Kesimpulan}

Pada bagian akhir penelitian ini penulis akan memaparkan beberapa kesimpulan yang dapat diambil dan didasarkan pada temuan hasil penelitian, yaitu:

1. Dengan adanya aplikasi GEOTRACK administrasi surat di PT Aneka Tambang Tbk, unit Geomin maka memudahkan karyawan khususnya Eksplorasi, GGD, Laboratorium, dan MRD dalam memonitor progres surat sampel dan koordinasi antarsatuan kerja.

2. Aplikasi yang dibangun dapat menampilkan secara online tentang informasi detail data tracking surat.

\section{Referensi}

Apriliah, W, R Ningsih, N Ariyanti, and T Haryati. 2018. Rancang Bangun Sistem Informasi Penerimaan Dan Pengeluaran Kas Pada Smp Islam Al Mujahidin Pamulang Tugas Akhir. INKOFAR 1(2): 29-39.

Azwardi. (2015). Menulis Ilmiah. Banda Aceh: Bina Karya Akamedika.

Fridayanthie, Eka W, Jimmy Charter. (2016). Rancang Bangun Sistem Informasi Simpan Pinjam Karyawan Menggunakan Metode Object Oriented Programming (Studi Kasus: PT. Arta Buana Sakti Tangerang). Jurnal Techno Nusa Mandiri. Vol.XIII, No. 2.
Khana Meutia Putri. (2016). Aplikasi Monitoring dan Tracking Pengelolaan Surat Berbasis Web (Studi Kasus: UPN "Veteran" Jakarta). Fakultas Teknologi Industri. UPN "Veteran" Yogyakarta.

M.Shalahudin, R. A. (2015). Rekayasa Perangkat Lunak (Terstruktur dan Berorientasi Objek). Bandung: Informatika

Pressman, R.S. (2015). Rekayasa Perangkat Lunak. Pendekatan Praktisi Buku I. Yogyakarta: Andi.

Sholikhah, Imroatus, Mahmud Sairan, and Nurfia Oktaviani Syamsiah. (2017). Aplikasi Pembelian Dan Penjualan Barang Dagang Pada Cv Gemilang Muliatama Cikarang. Jurnal Teknik Komputer Amik Bsi volIII(no1): 16-23.

Tabrani, Muhamad, and Insan Rezqy Aghniya. (2019). Impelemntasi Metode Waterfall Pada Program Simpan Pinjam. Jurnal Interkom 14(1): 44-53.

Yustiana Muti, Fajar Agustini, and Verry Riyanto. (2015). Sistem Informasi Penjualan Tas Berbasis Web Menggunakan Metode Waterfall (Studi Kasus: Apple Bag's Collection Bekasi). KNiST. 242-246.

Yudha Juniardi, Nur Iskandar, Tri Rahayu. (2018). Perancangan Sistem Informasi Penyewaan Gedung Pada Gedung Komando Kopassus Berbasis Web. INFORMATIK Vol 14, No. 2. 57-64. 